\title{
The Realistic Predicament and the Path Selection of Secondary College Governance
}

\author{
Gao Jie \\ School of education, Tianjin University \\ Tianjin, China
}

\author{
Shiming Zhu \\ School of education, Tianjin University \\ Tianjin, China
}

\begin{abstract}
This paper aims to strengthen the scientific governance of secondary college which is also an important way to straighten out the university governance and promote the construction of modern university system, and also an important entry point for comprehensively deepening the all-round education reform and promoting the "educational modernization 2030". By means of the combination of literature analysis and practice, this paper explores the real dilemma in the governance of middle schools. The paper also presents the problems of secondary college governance, such as the lack of autonomy, the symbolic assessments of the leadership, the inadequacy of teachers' internal motivation and the absence of multiple parts. The paper indicates that the establishment of a good schoolcollege relationship is the key to the promotion of the secondary college governance. In addition, it is also important to optimize governance in the aspects of leadership, teacher integration and democratic management.
\end{abstract}

Keywords-Secondary college; Governance; Realistic predicament; Path selection

\section{INTRODUCTION}

The constitution of the Communist Party of China (Amendment) adopted by the nineteen Party of the Communist Party of China put "advance the modernization of national governance system and governance capacity" into the party constitution, which is the general goal of comprehensively deepening the reform of socialism with Chinese characteristics in the new era. The reform of higher education as an important area of deepening reform should consciously around this goal, which improving the scientific and standard higher education governance system to form a high level of governance ability [1]. With the continuous optimization of the university governance structure and the downwardness of management, secondary college plays an increasingly important role in improving the quality of education and highlighting the advantages of characteristics. To promote the scientific management and healthy development of the secondary college has become an inevitable trend under the background of university governance. Therefore, we should deeply analyze the existing problems of the secondary colleges in our country and on this basis we propose the optimization path. It has positive and practical significance.

\section{SECONDARY COLLEGE GOVERNANCE}

In 1984, the Dalian University of Technology first implemented the college system and became the earliest university in China. In the wave of popularization of higher education, the number of secondary colleges in our university has increased dramatically. Up to now, the college system has become the basic choice of our university organizational structure [2].

The construction of a modern university system based on the core of university governance has become the basic consensus in the field of higher education. The academic research on university governance in China has been refined and deepened. Many theoretical achievements have been achieved. It cannot be ignored that the secondary college, as a specific practitioner of university running activities, undertakes the functions of personnel training, scientific research and social services. The healthy development of the secondary college is the fundamental guarantee for the high quality development of the university. The governance structure, decision-making system, participation and supervision mechanism of the secondary college are all related to the system of university Governance. The governance of the university and the governance of the secondary college are complementary and mutually reinforcing. The smooth implementation of university governance can provide an active reform atmosphere and an independent governance environment for the secondary college. The scientific governance of the secondary college can optimize the internal longitudinal governance structure of the university so as to give full play to the advantages of the secondary colleges. In this way, the overall optimization can be achieved. However, compared with university governance in policy and practice level, the attention of secondary college governance is not high at present. We should pay full attention to the secondary college governance. It is necessary to carry out deep exploration and practice [3]. 


\section{GOVERNANCE DILEMMA}

To a certain extent, the secondary college governance is more like symbolic governance. As professor Wang said, it is more time for secondary college governance to meet the needs of university governance [4]. In the practice of secondary college governance, there are still many problems.

\section{A. The traditional relationship is ingrained and the secondary college lacks autonomy}

In the gradual transformation of connotative development, the evaluation index of talent cultivation quality, scientific research level and social service ability is more and more refined and the evaluation level is gradually moving down. The secondary college's dominant position is increasingly prominent. Under the influence of highly centralized management system, universities and secondary colleges have been in the relationship of dominance and dependency, strong and weak position. Power runs from top to bottom. In terms of power allocation, there are more concerns about party power, government power and administrative power, while less attention is paid to the healthy development of grass-roots organizations. Secondary colleges are under direct control. At the same time, a large number of administrative departments are set up in the university and each department exercises certain administrative power. The secondary college, as an organization, needs to complete the work assigned by various departments. In this way, it is easy to be over administrative. Under the linear and hierarchical system, the secondary colleges are busy completing all kinds of instructions and ignoring the characteristic development of the discipline. The status of the main body of the school is not effectively implemented.

\section{B. The assessment of the leading group is symbolic}

With the mainstream of two-level management system in university, the responsibility of the secondary college is more important in the talent training, academic research and social service. Leadership plays an important role in the overall situation, especially the top leaders of the Party and government. They are the leading figures in the construction of the College. At present, the management system of the common responsibility of the party and the government is generally carried out in the universities of China. In universities, the Party committee is the political core of the college and the executive team is responsible for the administrative affairs. The Party committee secretary is appointed by the Party committee of the school. The Party committee secretary of college is responsible for the Party committee of the school. The president is appointed by the principal and is fully responsible for the scientific research and other administrative work of the college. The president is responsible to the principal. As a result, the appointment and assessment of the top leading group relies on the school level unilaterally, which is easy to cause the situation of symbolization and formality. It cannot really play the role of supervising and evaluating the leaders. It is worth noting that administrative power is still in a strong position in the game with academic power. The administrative power has maintained a consistent superiority in the resources allocation, title evaluation and teacher assessment of the secondary college. Unlike the principal's administrative level tenure system, the executive level of the dean is incumbent system. Once they leave, they return to the role of the professor. In such a case, the dean should also take into account the personal academic development while he is dealing with the academic affairs. It is easy to find the phenomenon of self employment and destroy the academic environment of the academy.

\section{The teachers' performance assessment generally despises teaching and emphasizes scientific research}

The secondary college as a concrete practitioner of the university has the two basic tasks of teaching and scientific research. The two cannot be neglected. In the construction of the teachers' team, the situation of despising teaching and paying attention to scientific research is revealed. It is difficult for the first-line teachers to exert their personal advantages in the hard task, which leads to the lack of effective integration of the faculty and the waste of human resources. The reason is that scientific research, compared to teaching, is able to gain income in a short period of time and its results are easily quantified. In the process of professional title evaluation and performance assessment, scientific research results can occupy an advantageous position. Teaching is quite the contrary. Talent training is a long process. At present, the teaching evaluation index is relatively vague and lacks a set of authoritative evaluation mechanism. Teachers' teaching achievements are not paid attention to [5]. In order to obtain praise and funds, the college requires teachers to make hard demands on scientific research. In a series of evaluation of teachers' performance assessment and title evaluation, the college attaches great importance to the quantitative research situation and takes a disregard of teaching. Driven by the collegiate system and personal interests, teachers naturally attach more importance to personal research results. However, some teachers who love teaching and are good at teaching are busy with the teaching and scientific research tasks required by the college. Their personal advantages cannot be brought into play or the results of teaching cannot be affirmed and recognized, and they will lose their enthusiasm for work.

\section{The channels of pluralistic subjects participation in governance are blocked}

The Institute has the political power centered on the Party committee, the executive power centered on the dean, the academic power led by professors, and the supervisory power with the staff and students as the main body. Pluralistic subjects should participate in the management of college. They should restrict each other and coordinate each other. But in the concrete practice, there are some disharmonious phenomena. First, the academic power is marginalized. The secondary college is originally an academic organization. However, due to the influence of traditional management system, college management still has official taste. Administrative power occupies the main right to speak. It makes academic power marginalized without enough space to play. Second, the teacher's discourse right is missing. The teachers have no right to examine the leadership of the college, which makes the status of the staff very weak. The opinions 
proposed by the staff are lack of operational safeguards. Their voices often come to nothing. Third, students participate in the surface. As the largest number of stakeholders in the secondary college, the power of the students to take part in governance is usually the most neglected by the college. The scope of students' participation in governance is extremely limited, and it is basically on the content of scholarship evaluation, community activities, etc., which do not involve major matters. Students are often the recipients of college policy making. The students' right consciousness and responsibility consciousness of participating in the college governance are not strong, and it is difficult to supervise the governance of the secondary college [6]. Fourth, the social participation channel is blocked. In the daily operation, the secondary college of our university does not make full use of the active role of social participation in the college governance. The communication between the college and the outside world is only on the surface, such as cooperation with business projects, the establishment of scholarships and inviting alumni to celebrate the anniversary. The channels of social participation in secondary college governance are not smooth and the depth is not enough. This is not conducive to the better development of the college.

\section{PATH SELECTION}

\section{A. Change management into governance and stimulate the vitality of school running}

Facing the dilemma of lack of motivation, changing the traditional way of excessive management and establishing a good school-college relationship are the key to reverse the dilemma. The vitality of the college directly determines the level and quality of a university, so more autonomy is needed to stimulate the vitality of the school. First of all, we should change the management system of non - decentralization in universities and carry out the shift of governance. With coordination instead of control, school carries out macro management. In the process of running schools, personnel, scientific research and other processes, school gives the college full autonomy and the right to decide, so all the vitality will be flowing fully. In addition, it is necessary to change the structure of power. The biggest feature of the bureaucracy is to follow the principle of hierarchy in order to ensure the smooth operation of the organization and achieve high efficiency [7]. However, under the realistic environment of the gradual expansion of the university functions, the bureaucracy system cannot meet the needs of development. It is the inevitable trend of the secondary college to adjust the operation structure of power properly and make the school-college relationship to be flattened.

\section{B. Separate the appointments and assessments of leadership ranks}

The management idea and method of the secondary college leading group directly affect the quality and talent training of the college, so the structure of the leading group is particularly important. In the appointment of the head of the party and the government of the college, the school should fully consider the organic combination of different factors such as age qualifications, acting style, subject background and ability. The leaders of the party and the government have complementary advantages and tacit understanding in order to form a joint force to lead the college to develop healthfully. In addition, in the form of leadership, we should abandon the traditional management concept promotion according to status. The promotion of excellent young cadres can bring new ideas and vitality to the governance of the college.

At present, universities basically carry out top-down evaluation system for college leaders. The appointment and examination of Party and government leaders is fully responsible for the school level. Due to the large number of colleges, it is difficult to grasp the specific operation of each college at the school level, which is likely to lead to improper evaluation. Therefore, it is particularly necessary to introduce a comprehensive evaluation system for college leaders, which is from school unilateral assessment to school assessment, peer assessment and staff assessment in parallel. At the school level, it is mainly responsible for assessing the performance of the leaders of the party and government, and evaluates them according to the formulation and completion of the goals. This is beneficial to the completion and improvement of the teaching, scientific research and social service in the College. The peer assessment is mainly about the coordination between the leaders of the party and government and the other members of the leading group. As a colleague of the "shoulder to shoulder", the evaluation of the same level can reflect the work ability and the style of the person. The staff assessment mainly reflects the satisfaction degree of the college grassroots level to the leading group. Teachers as the frontline of teaching and scientific research work are best to realize the problems existing in the operation of the college. The introduction of teaching staff level assessment can help college leaders to listen to the opinions and suggestions of the staff in an open-minded way, and effectively solve the specific problems in the development of the college. In this way, the assessment and evaluation for the party and government leaders can be combined in an all-round way, which can avoid the bad phenomenon of symbolic assessment and evaluation. Moreover, it also plays a positive role in the construction of the leading group of the secondary college, which is beneficial to the formation of the leadership resultant force and the better development of the college. 


\section{Balance teaching and scientific research and strive for the overall optimization of teachers}

For the present situation of excessive emphasis on scientific research work of teachers in the college, it is not only to carry out the educational advocacy of the spiritual level, but also to make improvements in the evaluation system and the incentive system. In the current teacher evaluation system, the provisions of scientific research indicators are clearer. However, it is vague in teaching and does not pay more attention to the process of teaching evaluation. The college should adhere to the status of teaching center and strictly implement the scientific evaluation mechanism with pluralistic evaluation subject. More importantly, the secondary college should take feasible and effective measures and guide teachers to establish values important in teaching and research from the system perspective. In addition, teachers' evaluation should also respect the differences among individuals. The college should give full play to the teachers' personal advantages and special strengths in meeting the basic teaching and scientific research. This can promote the development of teachers' personality and strive to achieve the optimization of the overall teachers of the college.

\section{Widen the participation channels of pluralistic subjects and take the road of common governance}

In order to make the college governance more scientific and democratic, we should actively build a platform for pluralistic subjects to take part in the governance. Making the main body participate in the decision is the only way to stimulate the vitality of the secondary college. Here are some ideas on the system, the students, the enterprises and the alumni. First, improve the organizational construction of the academic committee of the secondary college. In view of personnel structure is not reasonable and a series of problems, at the time of the establishment of a committee, the college should make a reasonable provision for the organizational rules, the scope of responsibility and the decision-making mechanism of the academic committee, especially in terms of restricting the number of professors with administrative posts, changing term of office and so on. Second, improve the subsequent execution mechanism of College Teachers' Congress. The college Teachers' Congress is an important system to supervise the operation of power. The college should set up a complete set of follow-up mechanism and put the resolution into the college's agenda. This can avoid meeting tend to be formal and hurting the confidence of the staff. Third, set up student representative organization and increase the students' right to speak. The student representative organization is divided by profession and is elected by students in every grade. The student representative organization is responsible for collecting students' opinions and convening meetings regularly. Bringing students into the decision-making system of secondary college governance, it can practically increase the students' right to speak. Fourth, we should fully absorb social forces and improve the governance of social participation. The secondary college should recognize the value of the external stakeholders, such as famous enterprises and excellent alumni. The secondary college should actively build up the platform and listen to their advice. This way can stimulate the innovative vitality of the college and promote the modernization of the college's governance ability.

\section{CONCLUSION}

To promote the modernization and science of the secondary college governance is a necessary requirement under the environment of university governance. In the face of resistance and problems in governance, choosing an effective path is the key to solving problems and continuing to move forward. We need to optimize the governance in the school relations, leadership system, teacher integration and democratic management, which can further promote the sound and stable development of the secondary colleges.

\section{REFERENCES}

[1] T. Qu, T. Wang, "The principle of due process in university students management from the perspective of rule of law," Academic Exploration, vol. pp. 52-57, May 2015. (In Chinese)

[2] Y. Xuan, "On the university-college relationship and the governance of secondary colleges at universities,"Modern Education Management, vol. pp. 1-5, July 2016. (In Chinese)

[3] D.X. Zhang, Y.F. Li, "School governance: an important issue of university governance,"China Higher Education Research, vol. pp. 6-11, March 2017. (In Chinese)

[4] J.H. Wang, "College's nature and governance,"China Higher Education Research, vol. pp. 13-17, January 2017. (In Chinese)

[5] B.B. Li, X.D. Xu, “Analysis and reflections on the imbalance between teachers' research and teaching abilities in university teachers' evaluation," Research in Higher Education of Engineering, vol. pp. 76$81+123$, February 2011. (In Chinese)

[6] X. Zheng, "The research of secondary college governance structure in China universities,"China University of Petroleum (East China), May 2014. (In Chinese)

[7] C.J. Wang, Y.F. Li, "The analysis of meaning and structural characteristics of bureaucracy-concurrently on Marx Webber's bureaucracy theory,"Academic Exchange, vol. pp. 56-60, May 2006. (In Chinese) 